\title{
Gelișmiş Ülkelerde Kurumsal Yapı ve Uluslararası Rekabet Gücü İlişkisi
}

\begin{abstract}
Aynur YILDIRIM1
\author{
Mehmet Faysal GÖKALP²
}

$\ddot{O} z$

Çalışmada 2000-2011 dönemi için, 23 kurumsal yapı değişkeninin kullanılmasıyla, 21 gelişmiş ülkenin bulunduğu ülke örnekleminde gelişmiş ülkelerde kurumsal yapının uluslararası rekabet gücü üzerindeki etkisi, "Panel Veri Analizi” yöntemi kullanılarak araştırılmıştır. Analiz sonuçları, yargı bă̆ımsızlı̆̆l, mülkiyet haklarının korunması, hukuk sisteminin bütünlüğ̈̈, marjinal vergi, politik özgürlükler, karaborsa döviz kuru, yabancı yatırımların kısıtlanması, bankacılık sisteminde özel kesimin payı, işe alma-asgari ücret, işe alma-işten çıkarma değişkenlerinin gelişmiş ülkelerdeki uluslararası rekabet gücü üzerinde pozitif; yasal düzenlemelerin niteliği, hükümet harcamalarl, transfer ve sübvansiyonlar, sivil özgürlükler, tarifeler, ticaret engelleri düzenlemeleri, toplu sözleşme ve askeri vesayet değişkenlerinin ise negatif etkiye sahip olduğunu ortaya koymuştur.
\end{abstract}

Anahtar Kelimeler: Kurum, Kurumsal Yapı, Uluslararası Rekabet Gücü, Gelişmiş Ülkeler

JEL Sinıflandirma Kodları: F43, O1

\section{Institutional Structure and International Competitiveness}

\section{Relationship in Developed Countries}

\begin{abstract}
This study analyzes the effects of institutional structure on the international competitiveness of developed countries econometrically by employing a "Panel Data Analysis" with a sample of 21 developed countries and 23 institutional variables for the period 2000-2011. The results of the analysis indicate that while judicial independence, protection of intellectual property rights, integrity of the juridical system, marginal tax, political freedoms, black market exchange rate, restrictions on foreign investment, private sector's share in the banking system, hiring-minimum wage, and hiring-dismissal have a positive effect; the nature of legal arrangements, government spending, transfers and subsidies, civil liberties, tariffs, regulations regarding trade barriers, collective bargaining, and military tutelage have a negative effect on the international competitiveness of developed countries.
\end{abstract}

Keywords: Institutions, Institutional Structure, International Competitiveness, Developed Countries

JEL Classification Codes: F43, O1

1 Öğr. Gör. Dr., Muğla Sitkı Koçman Üniversitesi, Dalaman Meslek Yüksekokulu, Pazarlama ve Dış Ticaret Bölümü, aynury@mu.edu.tr

2 Prof. Dr., Muğla Sitkı Koçman Üniversitesi, İktisadi ve İdari Bilimler Fakültesi, İktisat Bölümü,mfaysal@mu.edu.tr 


\section{A. YILDIRIM - M. F. GÖKALP}

\section{GİRİş}

Uluslararası rekabet gücünü etkileyen faktörler genel olarak verimlilik, işgücü piyasalarındaki esneklik düzeyi, teknolojik yenilikler, girişimcilik, sanayinin yeniden yapılanması, devletin ekonomideki yeri ve ekonomiye devlet tarafindan yapılan müdahaleler şeklinde belirtilmektedir (Bakımlı, 2005). Bu faktörlerin temelinde ise, ülkenin sahip olduğu kurumsal yapı yer almaktadır. Etkin kurumsal yapı, yukarıda sayılan faktörleri olumlu yönde etkileyerek uluslararası rekabet gücüne önemli katkılarda bulunmaktadır.

Kurumcu iktisat, ülkelerin gelişmişlik düzeylerinin belirlenmesinde yatırımı, istikrarı, güveni ve beşeri sermayeyi geliştirmeyi sağlayan, mülkiyet hakları sisteminin açıkça tanımlandığı, rekabete aykırı davranışları engelleyen, işlem maliyetlerini düşüren, hukukun üstünlüğüne önem veren, yapısal değişimi kolaylaştıran, üretim faktörlerinin daha verimli dağılmasını sağlayan iyi kurumların rolü olduğunu ileri sürmektedir. Söz konusu bu kurumlar, ülkelerin yüksek kalkınma düzeyine ulaşmalarına yardımcı olmaktadır.

Çalışmanın amacı, kurumsal yapının uluslararası rekabet gücü üzerindeki etkisini gelişmiş ülkeler için ortaya koyabilmektir. Bu amaçla ilk olarak kurum kavramı açıklanmış, ardından kurum ve ekonomik yapı ilişkisi kurulmaya çalışılmıştır. Daha sonra gelişmiş ülkelerdeki kurumsal yapı özellikleri ortaya konularak, kurumsal yapının uluslararası rekabet gücü üzerindeki etkisi ampirik olarak araştırılmıştır.

\section{KURUM KAVRAMI}

Kurum, insanlar tarafından tasarlanıp, oluşturulan kurallar bütünü ve birbirleri ile etkileşimlerinde, insanların davranışlarını sınırlandıran "oynanan oyunun kuralları" şeklinde ifade edilmesinin yanı sıra, bireylerin kendilerine has davranışları olarak da görülmektedir. Kurumları "oynanan oyunun kuralları" şeklinde ifade eden tanımlarda kurumlar, insanlar tarafindan oluşturulan kurallar bütünü olarak benimsenmektedir (North, 2010: 10). Bu görüşe göre kurumlar, "insanlar arasındaki etkileşimi biçimlendiren, insanların getirdiği kısıtlamalardır" 
(Luiz, 2009: 60; Keizer, 2007: 1; Grossman ve Helpman, 2002). Bu çerçevede Williamson (1985) kurumları, "piyasalar ve hiyerarşiler gibi alternatif organizasyonel mekanizmalar” olarak tanımlamıştır. Yine ona göre kurum, “oyunun kurallart”dır ve bu oyundaki oyuncular (bireyler) bu kurallara göre hareket etmektedir (Williamson, 2000: 595).

Temelinde alışkanlıklara yer veren tanımlara göre kurum, iktisadi bireylerin etkileşimlerini kapsamaktadır ve "yol- yordam”, "alışkanlıklar” ve "değerler” gibi kimi ortak kavramlar çerçevesinde nitelendirilmektedir (Hodgson, 1998: 167; Nelson, 2007: 322). Bireyler, kurumların oluşturduğu kısıtların işleyişi ile uyumlu alışkanlıklar edinmektedir (Hodgson, 2004). Veblen (1919) kurumu, "belirli bir dönemde yaygın olarak kabul gören düşünce ve davranış alışkanlıkları" olarak ele alırken; Hamilton (1932) kurumu, "sürekliliği olan düşünce ve eylem tarzl” olarak tanımlamışırı. Commons ise kurumu, "bireysel davranışların, genişlemelerini ve yayllmaların kisitlayarak, kontrol altında tutan bir toplu eylemlilik" diye tanımlamıştır (Commons, 1931: 648). Kurumlar, "toplumu tanımlayan ve oluşturan sosyal çimentoyu oluştururlar" (Kasper ve Streit, 1998: 4; Marangos ve Astroulakis, 2009: 1). Mitchell tarafından yapılan tanımda kurum, "geniş kabul gören iyi düzeyde standartlaşmış sosyal alışkanlıklar” olarak belirtilmiştir. Ayres ise kurumları, "menkıbeler, geçmişten kalan inançlar, statü ve toplumun hiyerarşik düzenine dayalı kuralların tümü" şeklinde yorumlamıştır (Demir, 1996: 174).

Kurumlar, bireysel davranışları sınırlandırırken altyapı ve üstyapı kurumları olarak farklı biçimlere bürünebilmektedir. Buna göre; üstyapı kurumları yasalar, anayasa, sözleşmeler ve mülkiyet hakları gibi toplumda genel olarak kabul edilmiş, meşruiyeti artık sorgulanmayan, yüksek yaptırım gücü bulunan ve resmi kurallar üzerine oluşturulmuştur. Sözü edilen bu yaptırımlar olmadan kurumlar kullanımsızdır. Kuralların içeriği kurumları desteklemektedir. Kurumların anahtar görevi, kuralları gelişigüzel değil sistematik olarak kolaylaştırmaktır. Sosyal bunalımların ve sosyal etkileşimlerin aşırı maliyetli olduğu yerde, güven ve işbirliği dağıtmaktır (Kasper ve Streit, 1998: 2). Üstyapı kurumları genellikle devlet tarafından oluşturulmakla birlikte devlet dışında, özel girişim ya da sivil 


\section{A. YILDIRIM - M. F. GÖKALP}

toplumu oluşturan diğer kesimlerin veya bireylerin aracıllğg ile de ortaya çıkabilmektedir (Olson, 1996: 3-4). Altyapı kurumları ise, ahlak, itibar, gelenekler, tabular ve ideolojiler gibi öğelerden oluşmaktadır. Toplumsal yaşamı düzenleyen resmi olmayan davranış kurallarını içerirler. Zaman içinde toplumların nasıl evrimleştiğini belirler, geçmiş kuşakların dünyayı algılayış ve olayları değerlendirişlerini yansitırlar; bu yüzden de, tarihsel değişimi anlamamıza yardımeı olurlar.

\section{KURUM VE EKONOMIK YAPI İLISSKISİ}

İktisatçılar tarafından her dönemde en çok tartışılan konular arasında ekonomik büyümenin çeşitli belirleyicileri yer almaktadır. Ekonomik büyümenin belirleyicileri yaklaşı belirleyiciler ve temel belirleyiciler olarak iki ana kısma ayrılmaktadır. Büyümenin yaklaşık belirleyicileri olan sermaye birikimi ve teknoloji düzeyi büyümeyi doğrudan etkilemektedir. Büyümenin temel belirleyicileri olan coğrafya, ticari entegrasyon, kültür ve kurumlar ise yaklaşık belirleyicileri etkilemek yoluyla büyümeyi dolaylı bir şekilde etkilemektedirler (Ünsal, 2007; Fedderke, 2001; Acar, 1998; Smith, 2004; Savaş, 2000; Gertler, 2010; Henry ve Miller, 2008; Kerber, 2006; Presbitero, 2006; Redek ve Susjan, 2005; Sachs, 2003; Barro, 1996).

Kurumsal yapı, ekonomik aktörlerin davranışlarını sınırlayan, yönlendiren ve motive eden bir işleve sahiptir (Acemoğlu, Johnson ve Robinson, 2004: 2). Dönüşüm maliyetleri ve işlem maliyetleri, kurumlar ve kurumsal yapının ekonomik büyümeyi etkileme kanallarından biridir (North, 2010: 13). Kurumların yapısına bağlı olarak ortaya çıkan işlem maliyetleri, etkili bir kurumsal yapının varlı̆g 1 halinde azalacaktır. Düşük işlem maliyeti ve bunun yol açtığı düşük üretim maliyeti sayesinde de ekonomik performans artacaktır (Ahsan, 2001: 8). Ayrıca kurumsal yapı, asimetrik bilgi ve sınırlı rasyonelliğin neden olduğu, ekonomik mübadelelerdeki fırsatçı davranış riskini ortadan kaldırarak, piyasada gerçekleşen bireyler arasındaki karşılıklı işbirliğini daha anlaşılır ve daha kolay hale getirerek, ekonomik yaşamın daha güvenilir ve dürüst olmasına yol açmaktadır. Buna bağlı olarak, birbirleriyle rekabet halinde olan ve belli bir riski üstlenmiş olan 
Dokuz Eylül Üniversitesi İktisadi ve İdari Bilimler Fakültesi Dergisi Cilt:31, Sayl:1, Yll:2016, ss. 1-34

girişimcilerin işlem ve bilgi maliyetlerini azaltmak yoluyla, onların risk almalarını ve yatırım yapmalarını teşvik etmektedir. Sonuçta, girişimcilerin ticari riskleri azalmakta ve kaynak etkinliği sağlanarak ticari faaliyetler daha kazançlı hale gelebilmektedir (Richter, 2005: 174; Nye, 2008: 76; Borrmann, Buse ve Neuhaus, 2006: 346).

Mülkiyet hakları ve yasalar girişimcilere güven vermediği sürece; kâr transferinin yasaklanması, kamulaştırma riski, yüksek vergi yükü, yüksek reel faizler, hammadde ve girdi maliyetlerindeki artışlar, yüksek enerji maliyetleri, yasalarda sık sık meydana gelen değişiklikler ve bu değişikliklere uyum sağlamada yaşanan zorluklarla her an karşılaşabileceği ihtimali, girişimcilerin ekonomik faaliyetlerinde tedirgin davranmalarına neden olmaktadır. Böyle elverişsiz bir ortamda, yüksek reel faizler nedeniyle girişimcilerin finansman maliyetleri artmakta ve uygun finansman kaynaklarının temin edilmesinde yaşanan zorluklar sonucunda üretim maliyetleri ve buna bağlı olarak da dönüşüm maliyetleri artmaktadır.

Günümüzde birçok ülke, mülkiyet haklarının korunması ve sürdürülmesini teşvik edecek güçlü kurumların oluşturulmasında başarısız kalmaktadır (Shirley, 2003: 3). Buna bağlı olarak, bu ülkelerde yaşayan bireylerin bir kısmı ekonomik faaliyetlerini yasal olmayan mekanizmaları kullanarak yönlendirmeye çalışmaktadırlar. $\mathrm{Bu}$ durumda, bu tür mekanizmaları benimsemeyen insanlarla aralarında güven sorunu ortaya çıkmaktadır. Düşük güven nedeniyle bir belirsizlik ortamı doğmakta, bu belirsizlik nedeniyle de girişimcilerin yeni yatırımlar yapma konusundaki cesaretleri kırılmakta, verimlilik azalmakta ve ekonomi durgunlaşmaktadır.

Kurumlar ya büyük oranda üretken ya da yıkıcı bir şekilde karşımıza çıkabilirler (North, 2010: 17). Belirsizliği azaltmak amacıyla oluşturulan kurumlar bazı durumlarda belirsizliğin artmasina da neden olabilirler (Wilson, 2007: 1099). Kurumların oluşumu, işleyişi ve gelişimi toplumlar arasında önemli ölçüde farklılaşmakta ve bu farklılıklar ülkelerin ekonomik performanslarında farklılı̆ga yol açarak, bazı ülkelerin fakir bazılarının ise zengin olmasında etkili olmaktadırlar 


\section{A. YILDIRIM - M. F. GÖKALP}

(Acemoğlu, 2008: 158). En iyi kurum ve politikalara sahip ülkeler, sahip oldukları potansiyelin büyük bir bölümünü kullanmayı başarabilirken; daha kötü kurum ve politikalara sahip olan ülkeler ise, bunu başaramamaktadır. Bu çerçevede ülkeler arası gelir farklılıkları, ülkelerin ekonomik politikaları ve kurumları arasındaki farklı1ıklara dayandırılabilmektedir (Olson, 1996).

Bazı toplumlar yatırımı, istikrarı, yenilik yapmayı, güveni ve beşeri sermayeyi geliştirmeyi sağlayan, mülkiyet hakları sisteminin açıkça tanımlandığı, rekabete aykırı davranışları engelleyen, toplumda güven ve sosyal işbirliğini sağlayan, işlem maliyetlerini düşüren, sosyal çatışma riskini azaltan ve hukukun üstünlüğüne önem veren, büyük ölçekli firmaların oluşturulmasına ve verimli teknolojilerin kullanılmasına olanak vererek üretkenliği arttıran, sanayileşme fırsatı yaratan, yapısal değişimi kolaylaştıran ve gerek ulusal gerekse uluslararası piyasalarda etkinliği arttıran 'iyi' ${ }^{3}$ kurumlara sahiptirler (Luiz, 2009: 58-72; Chen, 2008: 429; Borrmann, Buse ve Neuhaus, 2006: 346; Mehlum, Moene ve Ragnar, 2006: 2-3; Acemoğlu, Johnson ve Robinson, 2002: 1236).

İyi kurumlar, makro ekonomik istikrarsılıkları ve krizleri azaltarak; bireyleri ve firmaları üretken yatırımlara teşvik etmek yoluyla toplam faktör verimliliğinin ve rekabet gücünün artmasını sağlayarak, iktisadi büyümeyi destekleyen ve ekonomiye olumlu etkileri olan kurumlardır (Chen, 2008: 420; Decker ve Lim, 2008: 715; Mijiyawa, 2008: 386-396; Rodrik ve Subramanian, 2003: 31; Acemoğlu vd., 2003: 49-50; Barro, 2002: 150; Hall ve Jones, 1999: 83). Toplumda doğru kurumların varlığı, ekonomik ilerlemenin ve verimliliğin anahtarı olarak belirtilmektedir (Nelson, 2007: 321). Sürdürülebilir büyüme iyi kurumların varlığını gerekli kılmaktadır.

\section{GELİŞMİS ÜLKELERDE KURUMSAL YAPI ÖZELLİKLERİ}

Gelişmiş ülkelerde faktörlerin daha verimli dağılmasını sağlayan daha iyi kurumlar bulunmaktadır. Söz konusu bu ülkeler, etnik ve sınıf kutuplaşmalarını iyi

\footnotetext{
${ }^{3}$ Literatürde 'İyi' (good) kurumlar ifadesinin kullanıldığı kaynaklar için bkz: Luiz, 2009; Chen, 2008; Birdsall, 2007; Cheptea, 2007; Levchenko, 2004; Acemoglu, Johnson ve Robinson, 2002; Temple, 2001; Aron, 2000.
} 
işleyen kurumsal yapı ile çözmektedir (Levchenko, 2004: 20). Böylece kurumlar, ülkelerin yüksek kalkınma düzeyine ulaşmalarına yardımcı olmaktadır. Gelişmiş ülkelerin ekonomilerini güçlendirmelerinde, kurumsal yapılarını değiştirerek, korumacı politikaların terk edilmesi; ticaretin önündeki engellerin kaldırılması ve ülkeye yabancı sermayenin çekilmesi; mülkiyet haklarının güvence altına alınması; ekonomik özgürlüğe tüm yönleriyle önem verilmesi; bilgi ve iletişim teknolojileri alanında büyük ölçekli yatırımların yapılması; eğitime, özellikle bilimsel eğitime ve teknolojik araştırmaya önem verilerek, bilgi tabanlı ekonominin oluşturulmaya çalışılması önemli bir etken olmuştur.

Avrupa tarihi incelendiğinde İngiltere, Hollanda, Almanya ve Fransa gibi ülkelerin ekonomilerini güçlendirerek, gelişmiş ülkeler arasında yer almalarında, kurumsal yapılarını değiştirerek, mülkiyet haklarını güvence altına almaları önemli bir rol oynamıştır (Acemoglu, Johnson ve Robinson, 2005: 433-440; Reverte, 2008). İngiltere'de elit gruplar ve bireylere yönelik özel ayrıcalıklar ve monopol haklar, piyasalara girişe ve ticarete getirilen engellere karş1l1k; rekabetçi piyasalara girişi, bireysel özgürlükleri ve hukukun üstünlügünü savunan politikalara yer verilmiştir. Böylece refah ve zenginliğe yönelik tavır ve tutumların değişmesi tüketim ve üretim yapısında değişmelere neden olmuştur. Buna bağlı olarak İngiltere'de önce finansal kurumlar gelişmiş, finansal ve ticari gelişme süreci ekonomik kurumlarda da büyük değişimler yaşanmasına yol açmıştır. Sonuç olarak ekonomik kaynakların dağılımı farklılaşmış, Sanayi Devrimi (1760-1829) ile sonuçlanan hızlı ekonomik büyüme sağlanmıştır. Sanayi Devrimi sadece İngiltere ile sınırlı kalmamış, Devrim ile birlikte gelişen teknolojileri kullanan ülkeler de zenginleşmiştir. Özetle, Sanayi Devriminin İngiltere'de başlaması politik bir devrimden geçmesi sonucunda olmuştur (Shirley, 2008: 144-151; Acemoglu, Johnson ve Robinson, 2004: 7; Deane, 2000: 245-249; Rosenberg ve Birdzell Jr., 1992: 199).

Gelişmiş ülkeler arasında yer alan Fransa'da 1789 'da gerçekleşen devrimle birlikte, yasalar önünde eşitlik, söz ve basın özgürlüğü, özel mülkiyetin dokunulmazlığ 1 ve vergilerin toplumda dengeli bir şekilde dağıtılması gibi olgulara 


\section{A. YILDIRIM - M. F. GÖKALP}

vurgu yapan, "İnsan ve Yurttaş Hakları Bildirisi” ilan edilmiştir. Avrupa tarihinde bir dönüm noktası olan Fransız Devrimi, dünyanın geri kalanında da, tüm düşünce ve kurumlarda derin etkiler bırakmıştır (Sander, 1998: 145-149). Dünyanın ikinci en büyük sömürge imparatoru olan Fransa, 20. yüzyılın başlarında da ikinci sanayi devriminin bilimsel ve teknik yeniliklerinden (fotoğraf, gramofon, elektrik, otomobil, bisiklet vb.) yararlanmış; sanat, kültür ve bilim alanlarında ön planda olarak, uluslararası diplomaside öncü bir rol oynamış ve uluslararası bir prestije sahip olmuştur. Ayrıca 20. yüzyıl, I. Dünya Savaşı'ndan büyük bir zararla çıkan Fransa için, derin bir kültürel değişimin yaşandığı bir dönem olmuştur. Savaş sırasında, ekonomik ve sosyal faaliyetlerin birçok alanında kadınlar, erkeklerin yerini almıştır. 1930'lu ve 1940'lı y1llarda ise, haftalık çalışma süresinin 40 saatle sınırlandırılması; iki haftalık ücretli izin hakkının zorunlu hale getirilmesi; işçilere grev hakkının verilmesi; bankalar ve büyük şirketlerin (enerji, ulaştırma, sigorta) millileştirilmesi; kadınlar için oy hakkı gibi radikal reformlar yapılmıştır. 1949'da NATO üyesi olan Fransa, diğer beş Avrupa ülkesiyle birlikte, 1951'de Avrupa Kömür ve Çelik Topluluğu (AKÇT)'nu kurarak, bugünkü AB'nin temellerini atmıştır (Meyer, 2008: 28-31). 1789'dan sonraki dönemde Fransa, kapitalist sanayileşen bir toplum olmuş, sosyal ve kurumsal özellikleriyle de bu durumu devam ettirmiştir. Fransa, endüstriyel kalkınmanın bölgesel ve sektörel alanını derinden şekillendirerek, özel yatırımlar için firsatlar vererek, her zaman ekonomik yaşamda temel bir güç olmayı başarmıştır (Skocpol, 1987: 201).

Dünyanın en büyük ekonomisi olarak kabul edilen Amerika Birleşik Devletleri (ABD) için 1880'ler, değişiklikler ve yeniden yapılanma dönemi olmuştur. ABD ekonomisi endüstri ağırlıklı bir ekonomiye dönüşerek Eski Dünya'nın ekonomik sömürgesi olmaktan çıkmıştır (Rosenberg ve Birdzell Jr, 1992: 244-248). İkinci Dünya Savaşı Amerika'nın kariyerinde bir endüstriyel ve askeri güç olarak dönüm noktası olmuştur. Savaş sırasında giyim, beslenme, ulaşım ihtiyaçları ve silahlandırmak için uygulanan yatırım programları ABD'nin endüstri gücüne destek sağlamıştır. Soğuk Savaş dönemi boyunca (1945-1990) inşa edilen savunma sektörünün temel think-tank ve arabulucu rolü üzerinden, bürokrasi tedrici bir 
biçimde özel sektör ile güçlü işbirliği bağları geliştirmiştir. Dolayısıyla ulusal güvenlik temeli üzerinde önemli bir kurumsal kapasite inşa edilmiştir. Devlet endüstrileşmede temel itici güç olmamasına karşın, bu süreç piyasa güçlerine terk edilmemiştir. Ekonominin koordinasyonu üstün örgütsel yetenekleri temsil eden şirketlere bırakılarak, anti-devletçi yönde bir gelişme anlayışı sağlanırken; ulusal devlet federal güvenlik kurumları yoluyla dışarıda gücün inşası üzerinde yoğunlaşmıştır. Endüstrileşmenin ilk dönemi ulusal devlet inşasıyla arka arkaya meydana gelmiştir. ABD'de endüstriyel ekonomi politikası, Güneyli ayrımcılık ve endüstriyel Kuzey ile tarımsal Güney arasındaki iç uyumsuzlukla şekillenmiştir. (Weiss ve Hobson, 1999: 255-264). ABD modern rekabet yasasının öncülüğünü yapmış ve şirketlerin evrimi üzerinde önemli bir etki yaratan Sherman Anti-tröst Yasası 1890'da yürürlüğe girmiştir. Yasanın uygulanmasıyla ilgili aksaklıklar nedeniyle 1914 tarihli Clayton Anti-tröst Yasası uygulamaya girmiştir. Gelişmekte olan bir ülke ile serbest ticaret anlaşması imzalamak istediği zaman yatırım kuralları ve fikri mülkiyetin korunmasına özen göstermiştir (Rodrik, 2009: 57234).

Yirminci yüzyılın ikinci yarısının ilk mucizevi kapitalist ülkesi olan Japonya'da endüstrileşme sürecinin başlarında, hükümetlerle güçlü bağlantıları olan büyük ölçekli aile firmaları, hükümetin de desteğiyle endüstriye hâkim güçlü Japon örgütleri olan "zaibatsu”lara (Mitsubishi, Mitsui, Sumitomo, Yasuda) dönüşmüşlerdir. Hükümetin mali yardım, vergi muafiyeti ve dış ticarette ayrıcalığa sahip olmak gibi kolaylıklar sağladığı zaibatsu'daki holding şirketler, şirket ağlarındaki ana endüstriyel firmalara sermaye sağlamışlardır. Japonya'nın II. Dünya Savaşı'nda yenilmesiyle, işgal kuvvetleri tarafından güçlü holding ağlarını zayıflatmak amacıyla, Japon ekonomisinin önemli kısımlarını kontrol eden zaibatsu yapısı dağıtılmıştır (Bhappu, 2001: 160-163). Japonya'da “zaikai”ler (iş çevresinin en üst düzey yetkilileri), özellikle güçlü iş federasyonları kanalıyla seslerini duyurarak, Japon politik karar verme mekanizmasına egemen olmuştur (Wolferen, 1992: 39-41). Japonya'da 1945 yılında sendikal özgürlük, kadınlara oy hakkı, serbest eğitim sisteminin kurulması, mutlakiyetçi siyasal rejimin ortadan 


\section{A. YILDIRIM - M. F. GÖKALP}

kaldırılması ve ekonomik sistemin demokratlaştırılması gibi alanlar üzerinde başlatılan ekonomik kalkınma seferberliği, zamanla Japon mucizesine dönüşmüştür. Japonya'da gerçekleştirilen reformlardan biri de politikayı temizlemek alanında olmuştur. İş çevreleri, iktidar şansının yüksek olduğu siyasi partilere seçim öncesinde çok büyük oranlarda mali destek sunarak, bu desteğin karşılığında da taleplerinin yerine getirilmesini sağlamaktaydılar. Bu nedenle 1992 yılında, seçim yasasının ve partilere bağışlarla ilgili kuralların patronaj sistemini ortadan kaldırıp, dürüstlüğü ve şeffaflı̆̆ 1 getirecek şekilde değiştirilmesiyle ilgili ilk adımlar atılmıştır. Bürokratların firmalarla değil de sektörel dernek veya birlik gibi kurumlarla temasta bulunuyor olmaları, rüşveti engelleyerek bürokrasinin temiz kalmasını sağlamıştır. Japonya'da başarılan ekonomik mucizenin, kültür mirasından devralınan ve işbirliği içinde çalışabilme yolunda sahip olunan eşsiz yetenek nedeniyle gerçekleştiği savunulmaktadır (Kozlu, 1994: 44-143).

Japon mucizesinde hükümet de önemli bir rol üstlenmiş̧ir. Japonya'da hükümet tüm sektörlerin desteklenmesi yerine, gelişme ve kalkınma potansiyeli gösteren sektörlerin desteklenmesini benimsemiştir. Bu amaçla yüksek kazanç esnekliğine, verimlilik artışının yüksekliğine ve çalışan başına yüksek katma değer yaratma gücüne bakarak ekonomik kalkınmanın gerçekleştirilmesinde kilit olarak gördüğü öncelikli sektörleri belirlemiştir (Kozlu, 1994: 42-142; Weiss ve Hobson, 1999: 200).

II. Dünya Savaşı'nın sonuna kadar Japonya'nın işgali altında bulunan Kore, savaştan kısa bir süre sonra bağımsızlığını kazanmıştır. Kuzey ve Güney Kore tamamen farklı şekillerde organize olarak, bütünüyle farklı ekonomik ve politik kurumlar benimsemişlerdir. Kuzey Kore, Sovyet Sosyalizmi ile sermaye ve toprak üzerindeki özel mülkiyetin kaldırılmasını öngören Çin Devrimi’ni izlerken; Güney Kore bunun yerine, kapitalist ekonomik kurumlar ve özel mülkiyet sistemini benimsemiştir.

Güney Kore'de 1961 y1lında gerçekleştirilen askeri darbe ile iktidara gelen hükümet, insan hakları ve siyasi özgürlükler bakımından baskı politikası uygulasa da, politikadan çok ekonomiye, diğer ekonomik sorunlardan çok ekonomik 
Dokuz Eylül Üniversitesi İktisadi ve İdari Bilimler Fakültesi Dergisi

Cilt:31, Sayl:1, Yll:2016, ss. 1-34

büyümeye önem vermiştir (Rodrik, 2000: 54). Yatırımların önündeki engellerin kaldırılmasının yanı sıra hükümet politikalarıyla yatırıma büyük sübvansiyonlar getirilmiştir. Örneğin, Hyundai, Daewoo, Samsung, Lucky-Goldstar (LG) gibi "chaebol" olarak adlandırılan dev holdinglere tekel ayrıcalıkları ve sübvansiyonlar verilmiştir. Güney Kore açısından ekonomik durgunluk y1lı olan 1980 yılında iktidar değişikliği yaşanmıştır. Yeni hükümet, demokratikleşme hareketlerinin artmasıyla ekonomik büyüme ve istikrarı sağlama konusunda istekli olmuştur. Güney Kore'de 1980'li yıllardan başlanarak 2000'li yıllara kadar sanayi faaliyetlerine ağırlık verilerek “ileri sanayi ekonomisi”nin oluşturulması amaçlanmıştır. Bu amaca yönelik olarak 2004 yılında bazı anahtar teknolojiler ${ }^{4}$ belirlenmiş ve bu alanlarda ilerleme sağlanması amaçlanmıştır. (Hira, 2009: 134; Shirley, 2008: 158).

Güney Kore'nin sanayileşme atılımında devletin ağırllğı yadsınamaz. Güney Kore'de devletin ağırlığı mülkiyet kanalıyla değil, bürokrasinin etkinliği sayesinde kendisini göstermiştir. Ülkenin gücünü yükseltmek isteyen bürokratik kadro ile kârlarını azami düzeye çıkarmak isteyen iş çevreleri birbirleri ile uyum içinde çalışmıştır (Kozlu, 1994: 107-151; Weiss ve Hobson: 1999: 178-179). Güney Kore'de devlet, sunduğu teşvik ve yardımları icraat kriteri temelinde vermiştir. Desteklediği firmaların ihracata yönelmeleri yanında yeni teknoloji getirmelerini, araştırma geliştirmeye kaynak ayırmalarını şart koşmuştur. $\mathrm{Bu}$ hedefi yakalayamayan grup ve şirketleri de, desteğini çekmek suretiyle cezalandırmıştır. Böylece, etkin ihracat stratejisinde yardım alan kişilerin tümü ve tüccarların çoğu er ya da geç ihracat yapmak zorunda kalmıştır.

Tablo 1'de 2010 yılı itibariyle, ABD'nin yanısıra Avrupa ve Asya'nın gelişmiş ekonomilerinden seçilen ülkelere ait kurumsal göstergeler özetlenmiştir. Kurumsal yapının değerlendirilmesinde kullanılan "politik özgürlükler" ve "sivil özgürlükler” göstergeleri, Freedom in the World Raporundan alınmıştır. Her iki göstergeye ait endeksler 1-7 arasında değerler almaktadır ve endeks değerlerinin

${ }^{4}$ Ekranlarda (LCD, LED vb.), akıllı robotlar, yeni nesil otomobiller, yeni nesil yarı iletkenler; dijital TV ve yayın "akıllı ev ağı”, "dijital içerik ve çözümler" yeni nesil pil ve biyomedikal olarak siralanabilir (Hira, 2009: 134). 


\section{A. YILDIRIM - M. F. GÖKALP}

düşük olması özgürlük düzeyinin yüksek olduğunu; yüksek olması ise özgürlük düzeyinin düşük olduğunu ifade etmektedir. Kurumsal yapının değerlendirilmesinde kullanılan diğer göstergeler için, Economic Freedom of the World Annual Report verileri kullanılmıştır. Kurumsal göstergelere ait endeksler 010 arasında değerler almaktadır. Değerlerin yüksek olması kurumsal yapı etkinliğinin yüksek olduğunu; değerlerin düşük olması ise kurumsal kalitenin zayıflı̆̆ını işaret etmektedir. Tabloda yer alan ülkeler "yargı bağımsızlığı" açısından incelendiğinde İngiltere, Japonya, ABD ve Fransa'nın yüksek oranda bağımsız işleyen yargı sistemlerine sahip oldukları görülürken; Güney Kore'de ise yargı sisteminin siyasi etkilere maruz kalarak işlediği görülmektedir.

Tablo 1. Gelişmiş Ülkelerdeki Kurumsal Göstergeleri (2010)

\begin{tabular}{|l|c|c|c|c|c|}
\hline \multicolumn{1}{|c|}{ ÜLKELER } & \multirow{2}{*}{ ABD } & \multicolumn{2}{c|}{ AVRUPA } & \multicolumn{2}{c|}{ ASYA } \\
& & EKONOMILERI & \multicolumn{2}{c|}{ EKONOMILERI } \\
\cline { 2 - 6 } & ABD & İngiltere & Fransa & Japonya & Güney Kore \\
\hline Yargı Bağımsızlığı & 6,57 & 8,66 & 6,50 & 8,05 & 4,59 \\
\hline Tarafsız Mahkemeler & 5,63 & 6,79 & 6,38 & 5,92 & 3,71 \\
\hline $\begin{array}{l}\text { Mülkiyet Haklarının } \\
\text { Korunması }\end{array}$ & 6,76 & 8,34 & 8,25 & 7,81 & 5,92 \\
\hline $\begin{array}{l}\text { Askeri Vesayet (Siyasi } \\
\text { İstikrar) }\end{array}$ & 6,67 & 10,00 & 9,17 & 8,33 & 6,67 \\
\hline $\begin{array}{l}\text { Sözleşmelerin } \\
\text { Uygulanabilirliği }\end{array}$ & 7,33 & 5,95 & 6,91 & 5,80 & 8,11 \\
\hline Hükümet Müdahalesi & 6,43 & 5,18 & 4,66 & 5,80 & 6,85 \\
\hline Politik Özgürlükler & 1 & 1 & 1 & 1 & 1 \\
\hline Sivil Özgürlükler & 1 & 1 & 1 & 2 & 2 \\
\hline Dış Ticarette Serbestlik & 7,65 & 8,43 & 7,68 & 7,19 & 6,68 \\
\hline Düzenlemelerin Kalitesi & 7,64 & 7,42 & 6,92 & 7,72 & 6,84 \\
\hline Rüşvet/Kayırma & 5,99 & 7,70 & 7,16 & 8,06 & 5,22 \\
\hline
\end{tabular}

Kaynak: Economic Freedom of the World Annual Report 2012 ve Freedom in the World 2013 verilerinden yararlanılarak hazırlanmıştır.

Tablo 1'e göre, "tarafsız mahkemeler" alt bileşeni açısından İngiltere, Fransa, Japonya ve ABD'de, diğer ülkelere kıyasla anlaşmazlıkların çözümü konusunda, 
sahip olunan yasal çerçeve itibariyle daha verimli ve yansız bir süreç izlenirken; Güney Kore'de izlenen sürecin, verimsiz ve manipülasyona daha yatkın olduğunu söyleyebiliriz.

Gelişmiş ülkeler, kapitalist girişimcilere daha etkin ve yaygın mülkiyet hakları tanımaya çok erken dönemlerde başlamıştır. Patent kanunları, icatları teşvik ederek onları koruma altına almıştır. Kapitalist mülkiyet haklarının ortaya çıkışıyla birlikte de yatırımlar teşvik edilmiştir. Yapılan yatırımların güçlü mülkiyet hakları ile korunmasının yanı sıra iyi icraatların ödüllendirilmesi (devlet teşvikleri), başarısızlıkların ise ağır bir şekilde cezalandırılması (verilen desteğin çekilmesi), bu ülkelerin ekonomik kalkınmalarında başarıyı getirmiştir. Gelişmiş ülkelere ait kurumsal yapı göstergelerinin yer aldığı Tablo 1'e göre, "mülkiyet haklarının korunması" göstergesi açısından sırasıyla İngiltere, Fransa, Japonya ve ABD’nin daha iyi konumda oldukları görülmektedir. Tablodan ülkelere ait verilere bakarak, bu ülkelerde mülkiyet haklarının kanunlarla açık ve iyi bir şekilde tanımlandı̆̆ 1 söylenebilir. Güney Kore'nin sahip olduğu değer çok düşük olmamakla birlikte, tabloda yer alan diğer gelişmiş ülkelerle karşılaştırıldığında mülkiyet hakları ve hukuk kurallarının yeterli ve açık bir şekilde tanımlanmadığını belirtebiliriz.

Ordunun siyasete katılımının bir ölçüsünü veren askeri vesayet (siyasi istikrar) açısından en başarılı olan ülkeler, sırasıyla İngiltere, Fransa, Japonya iken bu ülkeleri, ABD ve Güney Kore izlemektedir. Tablo 1'deki veriler göz önünde bulundurularak, "sözleşmelerin uygulanabilirliği” alt bileşeni açısından değerlendirilen ülkeler arasında en iyi durumda olan ülkenin, Güney Kore olduğu görülmektedir. Diğer tüm ülkelerin 5'in üzerinde derecelere sahip olması nedeniyle, sözleşmelerin uygulanabilirliği açısından zayıf yönleri olmasına rağmen, iyi konumda oldukları söylenebilir.

"Hükümet müdahalesi” göstergesi, transferler ve sübvansiyonlar, devlet işletmeleri ve yatırımları ve marjinal vergi oranı şeklindeki alt bileşenlerden oluşmaktadır. Tablo 1'deki ülkeler arasında yer alan Fransa'daki hükümet harcamalarının en yüksek düzeyde olduğunu görmekteyiz. "Dış ticarette serbestlik" göstergesi açısından incelenen ülkelerin tamamının 5'in üzerinde değerler aldıkları 


\section{A. YILDIRIM - M. F. GÖKALP}

ve dış ticaretin serbestleştirilmesine yönelik politikalar açısından iyi konumda oldukları görülmektedir. İngiltere'nin en liberal dış ticaret politikalarını izlediğini söyleyebiliriz. İngiltere’yi Fransa, ABD, Japonya ve Güney Kore izlemektedir.

Gelişmiş ekonomiler politikayı temizlemek alanında da adımlar atmış ve bunun ekonomik kalkınmalarına yansımalarını görmüşlerdir. İş çevrelerinin, siyasi partilere sundukları mali destekler karşılığında çıkarları doğrultusunda taleplerde bulunmalarını engellemek amacıyla, seçim yasası ve partilere bağışlarla ilgili kurallar, patronaj sistemini ortadan kaldırıp, dürüstlüğü ve şeffaflığı getirecek şekilde değiştirilmiştir. Gelişmiş ülkelerin sosyal refah kurumları açısından ilerleme göstermesi de, kurumsal yapılarının güçlenmesini sağlamıştır. Sosyal refah kurumlarının gelişmesinde, oy verme hakkının yaygınlaşmasıyla siyasi gücü artan halk kesimlerinin ve sendikal hareketlerin etkisi büyük olmuştur. Tablo 1'de yer alan veriler politik ve sivil özgürlüklerin değerlendirilmesi açısından incelendiğinde, tüm ülkelerin gerek politik özgürlükler gerekse sivil özgürlükler açısından özgür oldukları söylenebilir.

Gelişmiş ülkelerde, çocuk işgücünün ve yetişkinlerin çalışma saatlerinin ve koşullarının düzenlenmesine yönelik yasaların çıkarılması, bankacılık sistemi ve sermaye piyasasının yeniden yapılandırılması, özelleştirme gibi kurumsal reformların gerçekleştirilmesiyle düzenlemelerin kalitesi arttırılmıştır. Tablo 1'de yer alan ülkelerin tamamının "düzenlemelerin kalitesi” alt bileşeni açısından 5'in üzerinde değerler aldıkları ve kaliteli düzenlemeler oluşturdukları görülmektedir.

Gelişmiş ülkelerde bürokratların firmalarla değil de sektörel dernek veya birlik gibi kurumlarla temasta bulunuyor olmaları, rüşveti engelleyerek, bürokrasinin temiz kalmasını sağlamıştır. Tablo 1'den "Rüşvet/kayırma" göstergelerine ait ülke verileri incelendiğinde, 5'in üzerinde dereceye sahip olan Japonya, İngiltere, Fransa, ABD ve Güney Kore'de rüşvet/kayırma ortamına izin vermeyen hükümet politikaları ve yasaların düzenlenmeye çalışıldığı görülmektedir. $\mathrm{Bu}$ ülkeler arasında, en iyi durumda olan ülkenin olan Japonya olduğu görülmektedir. 


\section{VERİ VE YÖNTEM}

\subsection{Kapsam ve Veri Seti}

Çalışmanın uygulama kısmında kurumsal yapının uluslararası rekabet gücü üzerindeki etkilerini ölçmek için, G7 ülkeleri temel olarak alınmış, G7 ülkelerinin yanı sıra kişi başına düşen geliri (2000-2011 yılları arası kişi başına düşen gelir ortalamas1), 25.000 \$ ve üzeri olan ülkeler de gelişmiş ülkeler grubuna dahil edilmiştir. Buna göre çalışmada ele alınan gelişmiş ülkeler; Avusturya, Avustralya, Belçika, Kanada, Danimarka, Finlandiya, Fransa, Almanya, İzlanda, İrlanda, İtalya, Japonya, Hollanda, Yeni Zelanda, Norveç, Singapur, İspanya, İsveç, İsviçre, Birleşik Krallık, ABD’den oluşmaktadır.

Kurumsal yapı değişkenlerinin rekabet gücü üzerindeki etkisinin ölçümünde, 2000-2011 yılları arasındaki 12 yıllık zaman dilimine ait veriler kullanılmıştır. Ülkelerin kurumsal yapısını ortaya koyacak veriler yaygın olarak, uluslararası kuruluşlar tarafından açıklanan endekslerden oluşmaktadır. Bu kuruluşlar arasında, PRS (Uluslararası Ülke Risk Rehberi), IMD (Uluslararası Yönetim Geliştirme Merkezi), Dünya Rekabet Yıllığı, Freedom House, Frasier Institue ve Gallup International sayllabilir. Verilerin derlenmesinde, World Bank (WGI: Worldwide Governance Indicators), International Monetary Fund (IMF) ve United Nations Economic Comission for Europe (UNECE) istatistiklerinden yararlanılmaktadır. Uluslararası kuruluşlar tarafından yayınlanan bu endeksler, daha çok uluslararası yatırımcıları bilgilendirmek amacıyla hazırlanmaktadır. Uzman görüşlerine dayalı olarak hazırlandıkları için, sübjektif bir niteliğe sahiptirler. Buna bağlı olarak, endekslerin hesaplama teknikleri, dayandıkları veri kaynaklarının yetersizliği ve tutarsızlığına yönelik eleştirilerle karşılaşılmaktadır (Mansfield, 2014). Ancak, buna rağmen, başka veri bulunmaması nedeniyle endekslerin, akademik araştırmalarda referans olarak kullanılması bir zorunluluk olarak ortaya çıkmaktadır.

Analizde kullanılan kurumsal yapı değişkenleri Tablo 2'de yer almaktadır (değişkenlere ait bilgiler Tablo 1 için yapılan açıklamalarda verilmiştir). 


\section{A. YILDIRIM - M. F. GÖKALP}

Tablo 2. Kurumsal Yapı Değişkenleri (Bağımsız Değişkenler)

\begin{tabular}{|c|c|}
\hline \multicolumn{2}{|c|}{ DEĞIŞSENLER } \\
\hline \multirow{5}{*}{$\begin{array}{l}\text { Hukuk Sistemi ve Mülkiyet Hakları ile } \\
\text { İlgili Göstergeler }\end{array}$} & Yargının Bağımsızlığı \\
\hline & Yasal Düzenlemelerin Niteliği \\
\hline & Mülkiyet Haklarının Korunması \\
\hline & Askeri Vesayet (Siyasi İstikrar) \\
\hline & Hukuk Sisteminin Bütünlüğü \\
\hline \multirow{3}{*}{$\begin{array}{c}\text { Hükümet Müdahalesi ile İlgili } \\
\text { Göstergeler }\end{array}$} & Hükümet Harcamaları \\
\hline & Transfer ve Sübvansiyonlar \\
\hline & Marjinal Vergi Oranı \\
\hline \multirow{2}{*}{$\begin{array}{l}\text { Hesap Verebilirlik, Şeffaflık, İfade } \\
\text { Özgürlüğ̈̈ ile İlgili Göstergeler }\end{array}$} & Politik Özgürlükler \\
\hline & Sivil Özgürlükler \\
\hline \multirow{4}{*}{$\begin{array}{c}\text { Dış Ticarette Serbestlik ile İlgili } \\
\text { Göstergeler }\end{array}$} & Tarifeler \\
\hline & Ticaret Engelleri ile İlgili Düzenlemeler \\
\hline & Karaborsa Döviz Kurları \\
\hline & Yabancı Yatırımların Kısıtlanması \\
\hline \multirow{4}{*}{$\begin{array}{c}\text { Piyasa Meşrulaştırıcı Kurumlar ile İlgili } \\
\text { Göstergeler }\end{array}$} & \multirow{2}{*}{ 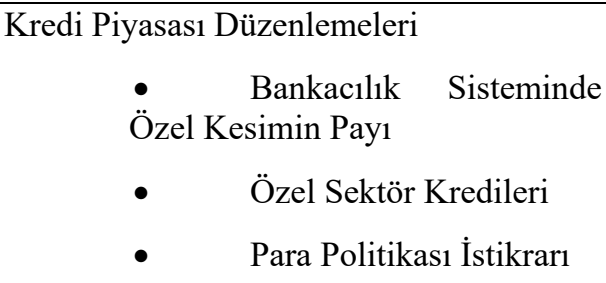 } \\
\hline & \\
\hline & $\begin{array}{l}\text { Emek Piyasası Düzenlemeleri } \\
\text { - İşe Alma ve Asgari Ücret } \\
\text { - İşe Alma İşten Çıkarma Düzenlemeleri } \\
\text { - Toplu Sözleşme }\end{array}$ \\
\hline & $\begin{array}{l}\text { İş Piyasası Düzenlemeleri } \\
\text { • } \\
\text { • } \\
\text { Bürokrasing kurma maliyeti }\end{array}$ \\
\hline $\begin{array}{c}\text { Piyasa İstikrarını Sağlayan Kurumlar } \\
\text { ile İlgili Göstergeler }\end{array}$ & Enflasyon \\
\hline
\end{tabular}

Kaynak: Economic Freedom of the World (EFW); Freedom House verileri kullanılarak hazırlanmıştır. 
Uluslararası rekabet gücü göstergeleri olarak literatürde çok sayıda değişken kullanılmaktadır. Ülkelerin sahip oldukları rekabet gücü, temelde GSYİH değişkeni üzerinden net bir şekilde izlenebildiği ve incelediğimiz ülkeler için en sağlıklı istatistiki veri olarak elde edebildiğimiz değişken, GSYIHH değişkeni olduğu için, "satın alma gücü paritesine göre kişi başına düşen GSYİH”, yapılan analizlerde bağımlı değişken olarak kullanılmıştır. Bağımlı değişkene ait veriler, Uluslararas1 Para Fonu'nun IMF Data and Statistics World Economic Outlook Databases veri tabanından elde edilmiştir.

Ayrıca, ülkelerin sahip oldukları emek ve sermaye miktarları kontrol değişkeni olarak analizlere dahil edilmiştir. İlgili değişkenlere ait istatistiki veriler sırasıyla, Worldbank Data Indicator veri tabanından ve IMF Data and Statistics World Economic Outlook Databases veri tabanından elde edilmiştir.

\subsection{Yöntem}

Kurumsal yapı ve uluslararası rekabet gücü arasındaki ilişkinin incelenmesi amacıyla kullanılan değişkenler, çalışmanın kapsamı ve incelenen dönem dikkate alındığında, panel veri analiz yönteminin kullanılmasının uygun olduğu sonucuna varılmıştır.

Panel veri analizine ait çözümlemeler Stata 11 paket programı yardımıyla yapılmıştır. Bu amaçla ilk olarak, Hausman testi yardımıyla sabit ve rassal etkiler tahmincilerinin seçimi yapılmış ve kullanılacak model belirlenmiştir (Tatoğlu, 2013). Ekonometrik analizlerde heteroskedasite (farklı varyans) problemi yatay kesit verilerle çalışma yapılırken karşılaşılan bir durumdur (Tatoğlu, 2013: 208210). Rassal etkiler modelinde birimlere göre heteroskedasitenin var olup olmadığ Levene, Brown ve Forsythe'nin testleri kullanılarak sınanmıştır. Birimler arası korelasyonun varlığını sinamak amacıyla, Friedman testi ve Frees testi

kullanılmıştır. Rassal etkiler üzerinden kurduğumuz modelimizde otokorelasyonun var olup olmadığı Baltagi-Wu'nun LBI testleri ile sınanmıştır. Rassal etkiler üzerinden kurulan model için yapılan testler sonucunda heteroskedasite, otokorelasyon ve birimler arasında korelasyon olması nedeniyle Driscoll-Kraay 


\section{A. YILDIRIM - M. F. GÖKALP}

standart hatalarla havuzlanmış en küçük kareler regresyonu tahmin edilmiştir (Tatoğlu, 2013: 267). Elde edilen sonuçlar üzerinden anlamsız olanlar tek tek analizden çıkarılarak en anlamlı model elde edilmeye çalışılmıştır.

\subsection{Analiz Sonuçları}

Gelişmiş ülkelerde kurumsal yapının uluslararası rekabet gücü üzerindeki etkisini ölçmek amacıyla yapılan ekonometrik analiz sonuçları Tablo 3'te gösterilmektedir. Tabloda yer alan analiz sonuçları üzerinden, gelişmiş ülkelerde kurumsal yapının uluslararası rekabet gücü üzerindeki etkisi açıklanmaya çalışılmıştır. Gelişmiş ülkeler için yapılan analiz sonucuna göre, bu ülkelerde emek miktarı \%10 arttı̆̆ında, kişi başına düşen GSYİH düzeyi \%1.07 artmaktadır. Yatırım miktarındaki \%10 düzeyindeki bir artışın ise, kişi başına düşen GSYIH düzeyini \%6.85 arttırdığı görülmektedir.

Gelişmiş ülkelerde hukuk sistemi ve mülkiyet haklarıla ilgili göstergelerden mülkiyet haklarının korunması, yargı bağımsızlığı ve hukuk sisteminin bütünlügü değişkenleri ile kişi başına düşen GSYİH düzeyi arasında pozitif ve istatistiksel açıdan anlamlı bir ilişki söz konusu iken; yasal düzenlemelerin niteliği ve askeri vesayet (siyasi istikrar) değişkenleri ile istatistiksel açıdan anlamlı fakat negatif bir ilişki bulunmuştur. Mülkiyet haklarının korunması değişkenine ait endeks değerlerindeki artış, mülkiyet haklarının yasalarla açık bir şekilde tanımlandığını ve korunduğunu ifade etmektedir. Tablo 3'e göre, mülkiyet haklarının korunmasındaki bir puanlık artış, kişi başına düşen GSYİH düzeyini \%2.7 arttırmaktadır. Mülkiyet haklarının iyi bir şekilde tanımlanması belirsizliğin azalmasına yol açmaktadır. Buna bağlı olarak kaynakların etkin bir şekilde kullanılması ve tahsis edilmesi ekonomik performansı pozitif yönde etkilemektedir (Khan ve Sokolof, 2001; Borrmann, Buse ve Neuhaus, 2006: 346; Opper, 2008: 392; Doyle ve Zarzosof, 2011; Le, 2009; Chen, 2008; Mijiyawa, 2008, Cheptea, 2007; Hall ve Jones, 1999; Svensson, 1998; Leblang, 1996; Knack ve Keefer 1995). 
Hukuk sistemi ve mülkiyet hakları ile ilgili göstergeler arasında yer alan hukuk sisteminin bütünlüğü değişkenine ait endeks değerlerinin artması, hukuk sisteminin tarafsızlığını ve gücünü ortaya koymaktadır. Tablo 3'e göre, hukuk sisteminin tarafsızlık düzeyindeki bir puanlık artış, kişi başına düşen GSYİH düzeyini \%3.1 arttırmaktadır. Ekonomik faaliyetleri sırasında yaşayabilecekleri olası riskler karşısında yasal düzenlemelere güvenilmesi, mülkiyet haklarının korunduğuna inanılması, ekonomik süreçteki belirsizliklerin ve buna bağlı olarak işlem maliyetlerinin azalmasına ve dolayısıyla toplumsal refahın artmasına yol açmaktadır (Doyle ve Zarzosof, 2011; Chen, 2008; Gani ve Prasad, 2006; Rodrik, 1999).

Hukuk sistemi ve mülkiyet hakları ile ilgili göstergelerden bir diğeri, yarg1 bağımsızlı̆̆ 1 değişkenidir. Yargı bağımsızlı̆̆ 1 değişkenine ait endeks değerlerinin artmas1, yarg1 bağımsızlı̆̆ının yüksek düzeyde olduğunu ortaya koymaktadır. Tablo 3'e göre, yargı bağımsızlığı değişkeninde meydana gelecek bir puanlık artış, kişi başına düşen GSYİH düzeyini \%5.8 arttırmaktadır. Etkin yarg1 sistemi, kurumsal kalitenin unsurlarından biri olarak ifade edilmektedir. Kurumsal unsurların etkinliği ölçüsünde, ülkelerin ekonomik performansı bundan olumlu etkilenecek ve uluslararası alandaki rekabet güçleri de artacaktır. Bağımsız yargıya sahip olmayan ülkelerde adaletten ve gerçek bir hukuk devletinden söz edilemez (Aron, 2000: 106; Elliott, 1997). 


\section{A. YILDIRIM - M. F. GÖKALP}

Tablo 3. Gelişmiş Ülkelerde Kurumsal Yapının Uluslararası Rekabet Gücü Üzerindeki Etkisi

\begin{tabular}{|c|c|c|}
\hline \multicolumn{3}{|c|}{ Bağımlı Değişken: Satın Alma Gücü Paritesine Göre Kişi Başına Düşen Gelir } \\
\hline Bağımsız Değişkenler & $\begin{array}{c}\text { Katsayı } \\
\text { (Standart Hata) }\end{array}$ & $\begin{array}{c}t \\
(P>|t|)\end{array}$ \\
\hline Sabit terim & $\begin{array}{c}\mathbf{3 . 3 0 4 6 8 5} \\
(0.6411804)\end{array}$ & - \\
\hline Emek & $\begin{array}{c}\mathbf{0 . 1 0 7 7 7 8 2} \\
(0.0175699)\end{array}$ & $\begin{array}{c}6.13 \\
(0.000)^{*}\end{array}$ \\
\hline Yatırım & $\begin{array}{c}\mathbf{0 . 0 6 8 5 1 0 8} \\
(0.0195433)\end{array}$ & $\begin{array}{c}3.51 \\
(0.002)^{*}\end{array}$ \\
\hline Yarg1 Bağımsızlığı & $\begin{array}{c}\mathbf{0 . 0 5 8 0 9 7 8} \\
(0.0226323)\end{array}$ & $\begin{array}{c}2.57 \\
(0.018)^{*}\end{array}$ \\
\hline Yasal Düzenlemelerin Niteliği (Tarafsız Mahkemeler) & $\begin{array}{l}\mathbf{- 0 . 0 4 9 0 6 6 4} \\
(0.0145432)\end{array}$ & $\begin{array}{l}-3.37 \\
(0.003)\end{array}$ \\
\hline Mülkiyet Haklarının Korunması & $\begin{array}{c}\mathbf{0 . 0 2 6 5 0 0 6} \\
(0.0111421)\end{array}$ & $\begin{array}{c}2.38 \\
(0.027)^{*}\end{array}$ \\
\hline Askeri Vesayet (Siyasi İstikrar) & $\begin{array}{l}\mathbf{- 0 . 0 6 9 6 8 4 5} \\
(0.016539)\end{array}$ & $\begin{array}{c}-4.21 \\
(0.000)^{*}\end{array}$ \\
\hline Hukuk Sisteminin Bütünlüğü & $\begin{array}{c}\mathbf{0 . 0 3 1 4 9 5 6} \\
(0.0093331)\end{array}$ & $\begin{array}{c}3.37 \\
(0.003)^{*}\end{array}$ \\
\hline Hükümet Harcamaları & $\begin{array}{l}\mathbf{- 0 . 0 2 1 1 3 2 3} \\
(0.0031154)\end{array}$ & $\begin{array}{c}-6.78 \\
(0.000)^{*}\end{array}$ \\
\hline Transfer ve Sübvansiyonlar & $\begin{array}{l}\mathbf{- 0 . 0 2 1 5 0 1} \\
(0.006475)\end{array}$ & $\begin{array}{c}-3.32 \\
(0.003)^{*}\end{array}$ \\
\hline Marjinal Vergi Oranı & $\begin{array}{c}\mathbf{0 . 0 3 6 4 3 6 8} \\
(0.0079343)\end{array}$ & $\begin{array}{c}4.59 \\
(0.000)^{*}\end{array}$ \\
\hline
\end{tabular}


Dokuz Eylül Üniversitesi İktisadi ve İdari Bilimler Fakültesi Dergisi

Cilt:31, Sayl:1, Yll:2016, ss. 1-34

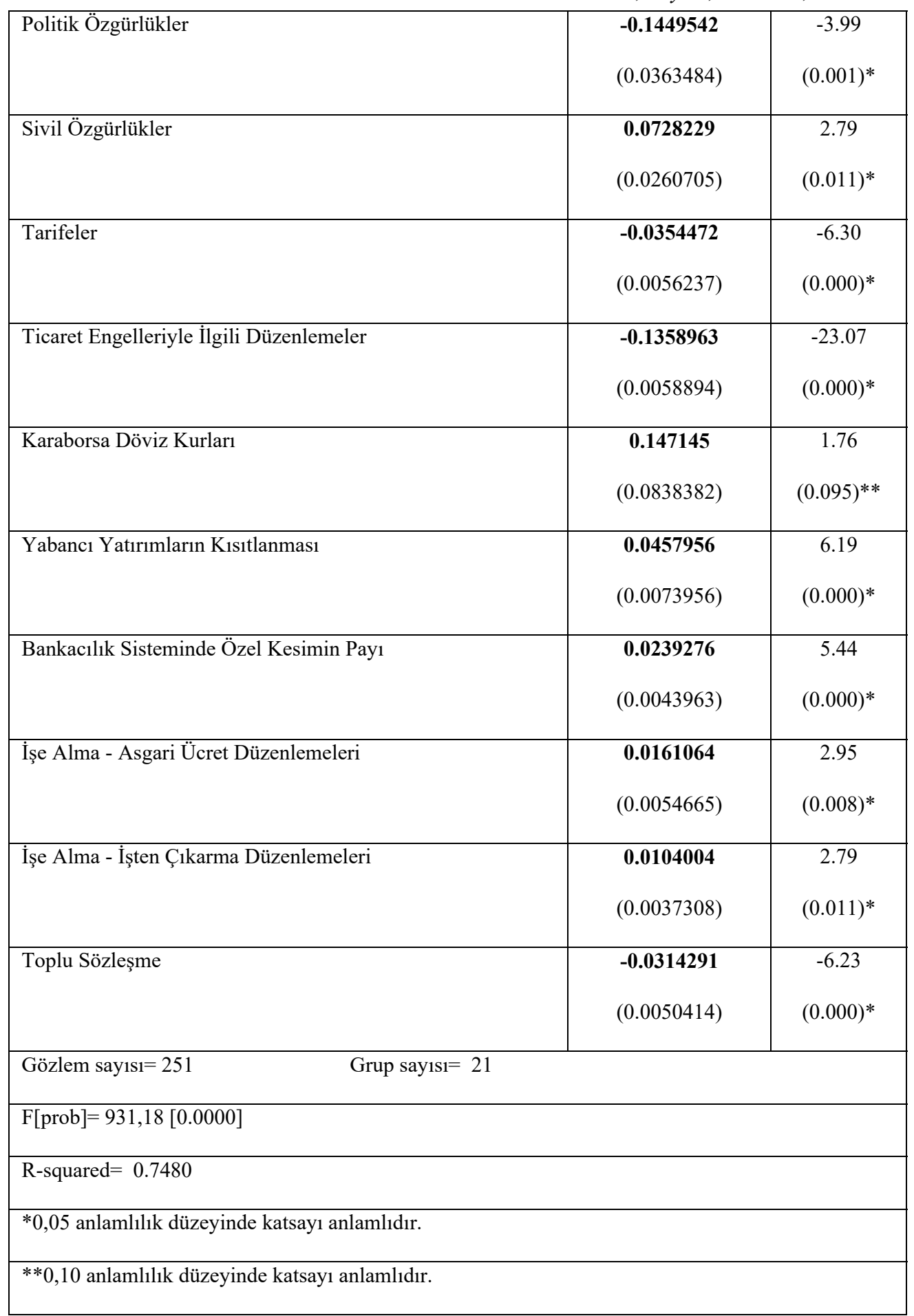

Ordunun siyasete katılımının bir ölçüsünü veren askeri vesayet (siyasi istikrar) değişkenine ait endeks değerlerindeki düşüş, siyasi istikrar düzeyinin düşük 


\section{A. YILDIRIM - M. F. GÖKALP}

olduğunu; endeks değerlerinin yüksek olması ise, siyasi istikrar düzeyinin yüksek olduğunu ifade etmektedir. Dolayısıyla Tablo 3'e göre, siyasi istikrar düzeyindeki bir puanlık artış, kişi başına düşen GSYİH düzeyini \%7 azaltmaktadır (veya siyasi istikrar düzeyindeki bir birimlik azalma, kişi başına düşen GSYİH düzeyini arttırmaktadır). Ortaya çıkan bu bulgu, demokrasinin ekonomik büyümeyi engellediğini veya ekonomik büyümenin demokrasiyi engellediğini iddia eden “çatışma perspektifi"ni (Sirowy ve Inkeles, 1990; De Hann ve Siermann, 1995; Nelson ve Singh, 1998) destekleyen bir sonuçtur.

Hukuk sistemi ve mülkiyet hakları ile ilgili göstergelerden biri olan yasal düzenlemelerin niteliği değişkenine ait endeks değerlerindeki düşüşler, yasal sürecin verimsiz ve manipülasyona tabii olarak işlediğini ifade ederken; endeks değerlerindeki artışlar ise, manipülasyonun olmadığg anlamına gelmektedir. $\mathrm{Bu}$ bağlamda Tablo 3'e göre, yasal düzenlemelerin niteliği değişkeninde meydana gelecek bir puanlık artış, kişi başına düşen GSYİH düzeyini \%4.9 azaltmaktadır. Diğer bir ifade ile manipülasyona tabii olarak işleyen yasal süreç kişi başına düşen GSYİH düzeyini olumlu etkilemektedir. Yasa tasarılarının hazırlandığı sırada holdingler, şirketler, işçi ve işveren sendikaları, ticaret ve sanayi odaları, diğer mesleki birlikler gibi çıkar gruplarının devreye girmesiyle, yasalardan kendi ortak çıkarları lehine bir takım teşvik politikalarının uygulanması sağlanabilmektedir. Teşvik politikalarıyla gelişme potansiyeli yüksek sektörlere ağırlık verilmesi ile ekonomik alanda pozitif katkılar elde edilebilmektedir. İhracat yapan endüstrilere verilen teşvikler ticaret dengesini iyileştirmekte ve ekonomik büyümeyi hızlandırmaktadır.

Hükümet müdahalesi göstergelerinden, hükümet harcaması değişkenine ait endeks değerlerindeki düşüşler yüksek oranlı hükümet harcamasının varlığını ifade ederken; endeks değerlerindeki artışlar ise devlet harcamalarının düşük olduğu anlamına gelmektedir. Dolayısıyla Tablo 3'e göre, hükümet harcamaları değişkenine ait endekste meydana gelen bir puanlık artış, kişi başına düşen GSYİH düzeyini \%2.1 azaltmaktadır. Diğer bir ifade ile devlet harcamalarının düşmesi, kişi başına düşen GSYİH düzeyini olumsuz etkilemektedir. Diğer taraftan, 
hükümet müdahalesinin diğer bir göstergesi olan transfer ve sübvansiyonlar değişkenine ait endeks değerlerindeki artışlar, düşük düzeyde sübvansiyon uygulandığı anlamına gelmektedir. Bu bağlamda Tablo 3'e göre, transfer ve sübvansiyonlar değişkeninde meydana gelecek bir puanlık artış, kişi başına düşen GSYİH düzeyini \%2.2 azaltmaktadır. Buna göre, sübvansiyon uygulamalarındaki azalmalar, kişi başına düşen GSYİH düzeyini olumsuz etkilemektedir. Her iki değişken için elde edilen bulgular, hükümet müdahalesinin ekonomik performans üzerinde olumlu etkiler yarattığını ortaya koymaktadır. Hükümet müdahalesi ile ekonomik büyüme arasındaki ilişkiyi inceleyen (Paldam ve Würtz, 2003) akademik çalışmaya göre, devletin ekonomideki ağırlığının optimal olduğu bir düzey bulunmaktadır. Devletin ekonomideki ağırlığının bu optimal düzeyin altında kalması durumunda, yani ekonomik özgürlüklerin daha yüksek olduğu düzeylerde ekonomik özgürlükler arttıkça (devletin payı küçüldükçe) ekonomik büyüme azalmaktadır. Dolayısıyla, devletin ekonomideki ağırlığının optimal düzeyin altında kalması durumunda, hükümet müdahalesi ekonomik performansa olumlu katkıda bulunmaktadır.

Tablo 3'e göre marjinal vergi oranı ve kişi basına düşen GSYİH düzeyi arasında pozitif ve istatistiksel açıdan anlamlı bir ilişki söz konusudur. Marjinal vergi oranına ait endeks değerlerindeki artışlar, marjinal vergi oranının düşük olduğu anlamına gelmektedir. Buna göre marjinal vergi oranı değişkeninde meydana gelecek bir puanlık artış, kişi başına düşen GSYİH düzeyini \%3.6 arttırmaktadır. Diğer bir ifade ile, marjinal vergi oranı düştükçe kişi başına düşen GSYİH düzeyi artmaktadır. Ekonomik birimler tarafından ödenen vergi oranlarındaki düşüşler, gelirin daha az kısmının devlete aktarılmasına yol açtı̆̆ından kullanılabilir gelir düzeyinde artış yaşanmasına neden olmaktadır. $\mathrm{Bu}$ durum ekonomik süreçte toplam harcamaları ve dolayısıyla yatırım ve üretim düzeyini olumlu etkileyerek ülkelerin uluslararası rekabet gücü üzerinde pozitif katkılarda bulunmaktadır.

Çalışmada kullanılan verilerden sivil özgürlük ve politik özgürlük bileşenlerine ait endeks değerlerinin düşmesi, sivil ve politik özgürlük düzeyinin arttığını; endeks değerlerinin artması ise, sivil ve politik özgürlük düzeyinin düştüğünü ifade 


\section{A. YILDIRIM - M. F. GÖKALP}

etmektedir. Bu bağlamda Tablo 3'e göre, gelişmiş ülkelerde politik özgürlükler değişkenindeki bir puanlık artış, kişi başına düşen GSYIHH düzeyini \%1.4 arttırmakta ve uluslararası rekabet gücünü pozitif yönde etkilemektedir. Siyasi gücü elinde bulunduran bireylerin bu gücü kullanma biçimleri, toplumların gelişiminde önemli rol oynamaktadır. Dürüst ve güvenilir kamu görevlilerinin kamu güvenini tesis etmeleri ve ekonominin karar birimleri için elverişli bir ortam meydana getirmeleri, piyasa mekanizmasının etkin bir şekilde işlemesini sağlayarak ekonomik gelişmeye katkıda bulunacaktır. Politik ve siyasi özgürlüklere sayg1 ortamında, siyasi gücü elinde bulunduranların toplumun ihtiyaçlarına cevap veren yatırımları hayata geçirerek toplumsal refahı amaçlamaları; ifade ve inanç özgürlüğüne sahip olarak güçlü bireysel hakları elinde bulunduran ekonomik birimlerin ise, ekonomik faaliyetlerini güvenli bir ortamda gerçekleştirmeleri kişi başına düşen geliri arttırmaktadır. Gelişmiş ülkelerde sivil özgürlükler için ortaya çıkan sonuç dikkat çekmektedir. Tablo 3'e göre, sivil özgürlükler düzeyindeki bir puanlık artış, kişi başına düşen GSYİH düzeyini \%7.3 azaltmaktadır. Bireylerin örgütlenme hakk1, hukukun üstünlüğü gibi güçlü bireysel haklara sahip olmaları, ekonomik faaliyetlerini güven içinde gerçekleştirmelerini sağlarken, diğer taraftan elde ettikleri bu gücün arkasında, ekonomik faaliyetleri sırasında verimlilik düzeylerinde azalmaların yaşanması ihtimali bu sonuca neden olmuş olabilir.

Gelişmiş ülkelerde kurumsal yapının uluslararası rekabet gücü üzerindeki etkisini ölçmek amacıyla yapılan analizde, dış ticarette serbestliğin ölçülmesiyle ilgili kullanılan değişkenlerin tamamı anlamlı sonuçlar vermiştir. Çalışmada kullanılan verilerden yabancı yatırımların kısıtlanması değişkenine ait endeks değerlerinin artması, yabancı yatırımlarla ilgili kısıtlamaların düşük, yabancı yatırımın yüksek düzeyde olduğunu ifade etmektedir. Tablo 3'e göre yabancı yatırımların kısıtlanması ve kişi başına düşen GSYİH arasındaki pozitif ilişkinin varlığı, yabancı yatırımlardaki bir puanlık artışın kişi başına düşen GSYİH düzeyini \%4.6 arttıracağını ifade etmektedir. Yabancı yatırımları kısıtlayacak düzenlemelerin bulunmaması, yabancı mülkiyetinin yaygın olması, yabanc1 yatırımcıların söz konusu ülkelerde kolaylıkla yatırım yapabilmeleri, mülkiyet 
Dokuz Eylül Üniversitesi İktisadi ve İdari Bilimler Fakültesi Dergisi

Cilt:31, Sayl:1, Yll:2016, ss. 1-34

haklarının yasalarla korunuyor olması, hukuksal açıdan yerli firmalarla eşit haklara sahip olmaları gibi kurumsal düzenlemeler, yabancı yatırımcıların belirlilik ortamında faaliyette bulunmasını sağlayacaktır. $\mathrm{Bu}$ durum, yatırımcıların kendilerini güvende hissetmelerine olanak verecek ve sonuç olarak artan yatırımlara bağlı olarak ekonomik performans pozitif yönde etkilenecektir.

Diğer taraftan karaborsa döviz kuru değişkenine ait endeks değerlerindeki artışlar, karaborsa piyasasının olmadığını ve ulusal paranın konvertibilitesinin yüksek olduğunu ifade etmektedir. Buna göre, karaborsa döviz kuru değişkeninde meydana gelen bir puanlık artış, kişi başına düşen GSYIH düzeyini \%1.5 arttırmaktadır. Diğer bir ifade ile, karaborsanın olmadığı, ulusal paranın tam konvertibl olduğu durumda kişi başına düşen GSYİH düzeyi artmaktadır. Çünkü konvertibilitenin tam olması, sermayenin dışarı kaçmasını engellemek; yabancı sermayenin ülkeye girişini kolaylaştırmak; malların en ucuz oldukları piyasalardan satın alınıp en pahalı oldukları piyasalara satılmasına olanak vermek; uluslararası ödemelerin kolaylıkla yapılabilmesine imkân tanımak gibi etkenlerle dünya ticaret ve mali akımlarının gelişmesine katkıda bulunmakta ve böylece ekonomide genişleme yaratmaktadır.

D1ş ticarette serbestliğin ölçülmesiyle ilgili kullanılan değişkenlerden ticaret engelleriyle ilgili düzenlemeler değişkenine ait endeks değerlerindeki artışlar, dış ticareti engelleyici politikaların uygulanmadığını veya çok düşük düzeyde uygulandığını; endeks değerlerindeki düşüşler ise, dış ticaret engellerinin yüksek düzeyde olduğunu ifade etmektedir. Dolayısıyla Tablo 3'e göre, ticaret engelleriyle ilgili düzenlemeler değişkeninde meydana gelecek bir puanlık artış, kişi başına düşen GSYİH düzeyini \%1.4 düşürecektir. Diğer bir ifade ile dış ticaret engellerinin uygulanması kişi başına düşen GSYİH düzeyini olumlu yönde etkilemektedir. Dış ticarette serbestlikle ilgili göstergelerden bir diğeri olan tarifeler değişkenine ait endeks değerlerindeki düşüşler, tarife oranlarının arttırıldığını; endeks değerlerindeki artışlar ise tarife oranlarının düşürüldüğünü ifade etmektedir. Tablo 3'e göre, tarifeler değişkeninde meydana gelen bir puanlık artış, kişi başına düşen GSYİH düzeyini \%3.5 düşürmektedir. Diğer bir ifade ile 


\section{A. YILDIRIM - M. F. GÖKALP}

tarife oranları düşürüldükçe, dış ticaret engelleri azaltıldıkça kişi başına düşen GSYIHH düzeyi azalmaktadır. Gelişmiş ülkeler, gelecekteki hızlı büyümeleri için kilit kabul edilen endüstrilerde karşılaştırmalı üstünlük yaratabilmek amacıyla koruyucu dış ticaret önlemlerine başvurabilmektedirler. Tarifelerin düşürülmesi, ülke içindeki üretim birimlerinin rekabet edemeyecekleri bir piyasaya açılmalarını sağlıyorsa, GSYİH düzeyinde düşüşler beklenebilir. Aynı şekilde tarifelerin yükseltilmesi yoluyla sağlanacak korumacılık, ithal mallarının iç piyasadaki üretimindeki artışın yanı sıra gelir ve istihdam artışını da sağlayabilecektir.

Kredi piyasası düzenlemelerinden özel sektör kredileri ve negatif reel faiz değişkenlerinin istatistiki olarak anlamsız çıktığı analizde, bankacılık sisteminde özel kesimin payı anlamlı sonuç vermiştir. Bankacılık sisteminde özel kesimin payına ait endeks değerlerinin artması, bankacılık sisteminde özel mevduatların payının yüksek olduğunu ifade etmektedir. Dolayısıyla Tablo 3'e göre, bankacılık sisteminde özel kesimin payındaki bir puanlık artış, kişi başına düşen GSYIH düzeyini \%2.4 arttırmaktadır. Kredi piyasasının düzenlenmesi, finansal serbestlik, bireylerin ve firmaların ekonomik faaliyetleri sırasında özgür davranabilmeleri, ekonomik performans üzerinde olumlu katkılarda bulunarak, uluslararası rekabet gücünü de pozitif etkilemektedir (Alzer ve Dadasov, 2013; Gwartney, Hall ve Lawson, 2010; Charnock, 2009: 87; Cheptea, 2007: 226; Powell, 2003).

Emek piyasası düzenlemelerinden işe alma-asgari ücret ve işe alma-işten çıkarma değişkenlerine ait endeks değerlerindeki artışlar, esnek emek piyasasının varlı̆̆ını ifade etmektedir. Bu bağlamda Tablo 3'e göre, işe alma-asgari ücret düzenlemelerindeki bir puanlık artış, kişi başına GSYİH düzeyini \%1.6 arttırırken; işe alma-işten çıkarma değişkenindeki bir puanlık artış, kişi başına düşen GSYIH düzeyini \%1.04 artırmaktadır. Diğer bir ifade ile kısa süreli istihdam sözleşmelerinin düzenlenebildiği, esnek bir yapıya sahip emek piyasasının varlığında, kişi başına GSYİH düzeyi olumlu etkilenmektedir. Esnek emek piyasası düzenlemeleri, genellikle ekonomik kriz dönemlerinde söz konusu olmakla birlikte, gelişmiş ülkelerde teknolojinin hızla gelişmesi ve sanayi sektöründen hizmet sektörüne geçilmesi gibi nedenler de, esnek emek piyasası düzenlemelerinin 
Dokuz Eylül Üniversitesi İktisadi ve İdari Bilimler Fakültesi Dergisi

Cilt:31, Sayl:1, Yll:2016, ss. 1-34

gerçekleştirilmesine yol açmaktadır. Yaşanan teknolojik gelişmeler ve ekonomik yapıdaki değişim sonucunda ortaya çıkan işsizlik düzeyindeki artışlar karşısında kısa süreli istihdam sözleşmeleri bir çözüm olarak ortaya konulabilmektedir. Böylece, istihdam ve üretimin devamlılığının sağlanması ekonomi üzerinde olumlu katkılarda bulunabilmektedir. Ayrıca gelişmiş ülkelerde çalışanlar, eğitim görme ve diğer aktivitelere katılma gibi nedenlerle de kısa süreli istihdam sözleşmelerini ve esnek uygulamaları tercih edebilmektedirler.

Emek piyasasının diğer bir göstergesi olan toplu sözleşme değişkenine ait endeks değerlerindeki düşüşler ise, şirketlerin toplu sözleşmeleri bağımsız bir şekilde yapamadıklarını, merkezileşmiş bir toplu sözleşmenin varlığını ifade etmektedir. Tablo 3'e göre toplu sözleşme değişkeninde meydana gelecek bir puanlık artış, kişi başına düşen GSYİH düzeyini \%3.1 azaltmaktadır. Firmaların toplu sözleşmeleri kendilerinin esnek bir şekilde yapabilmeleri, kişi başına düşen GSYIH düzeyini olumsuz etkileyebilmektedir. Firmaların sözleşme kurallarını kendilerinin belirlediği durumda, çalışanların eğitim, iş sağlığı, sosyal güvenlik, ücret gibi alanlardaki hak talepleri karşısında daha savunmasız kalabildikleri, buna bağlı olarak, firmalar yerine merkezileşmiş toplu sözleşme uygulamalarının yapılmasının firmalar adına pazarlık gücünü arttırdığg daha önce de belirtilmişti.

\section{SONUÇ}

Gelişmiş ülkelerin kurumsal yapılarının incelenmesi neticesinde, söz konusu bu ülkelerde genellikle korumacı politikaların terk edildiği, ticaretin önündeki engellerin kaldırıldığı, yabancı sermayenin getirilmesi ve mülkiyet haklarının güvence altına alınması konusunda kapsamlı düzenlemelerin yapıldığı, ekonomik özgürlüğe tüm yönleriyle önem verildiği, bilgi ve iletişim teknolojileri alanında büyük ölçekli yatırımların yapıldığı, eğitime özellikle bilimsel eğitime ve teknolojik araştırmaya önem verildiği, bilgi tabanlı ekonomi oluşturulmaya çalışıldığı görülmektedir.

Analiz sonuçları, kurumsal yapı göstergelerinden yargı bağımsızlığı, mülkiyet haklarının korunması, hukuk sisteminin bütünlüğü, marjinal vergi, politik özgürlükler, karaborsa döviz kuru, yabancı yatırımların kısıtlanması, bankacılık 


\section{A. YILDIRIM - M. F. GÖKALP}

sisteminde özel kesimin payı, işe alma-asgari ücret, işe alma-işten çıkarma değişkenlerinin gelişmiş ülkelerde uluslararası rekabet gücü üzerinde pozitif bir etkiye sahip olduğunu ortaya koymuştur. Diğer taraftan yasal düzenlemelerin niteliği, hükümet harcamaları, transfer ve sübvansiyonlar, sivil özgürlükler, tarifeler, ticaret engelleri ile ilgili düzenlemeler, toplu sözleşme ve askeri vesayet (siyasi istikrar) değişkenleri, gelişmiş ülkelerde uluslararası rekabet gücü üzerinde beklentilerin tersi bir etkiye sahip iken; para politikası istikrarı ve enflasyon değişkenleri ise anlamsız çıkmıştır.

Buna göre, iyi kurumlar seti olarak sunulan düzenlemelerin, ülkelerin kendilerine özgü yerel koşulları ile birleştiğinde beklenenin tersi etkilerde de bulunabileceği söylenebilir. Bu nedenle, küreselleşme olgusunun yol açtığı rekabet gücünün arttırılması isteğiyle (rekabet baskısı ile) gerçekleştirilen kurumsal yapı reformları, amacına ulaşmayabilmekte ve bu amaçla çıkarılan yasal düzenlemeler, sadece kağıt üzerinde alınan kararlar olarak kalabilmektedir. Toplumlar benzer kurumlar oluştursalar bile zaman içerisinde kurumların işleyişinde ve toplumların gelişiminde farkl11ıklar görülebilmektedir. İyi kurum olarak ifade edilen düzenlemelerin uygulandığı ülkelerde başarıya ulaşabilmesi için, ülkenin ekonomik, sosyal, siyasi alanda sahip olduğu yerel koşullar göz önünde bulundurularak, standart politika reformlarının yerel bilgi ile desteklenmesi ve ülkenin koşullarına göre uyumlaştırılması gerekmektedir.

Sonuç olarak, iyi kurumlar diye her ülkede geçerli olan bir kurumsal düzenleme seti bulunmadığı ileri sürülebilir. İyi kurumdan kastedilen şey, ekonomiyi genişletici, büyütücü, rekabet gücünü arttırıcı unsurlar ise ve kurumlar, toplumda oynanan oyunun geçerli kuralları olarak tanımlanıyor ise, her toplumda oynanan oyunun kurallarının birbirinden farklı olması, iyi kurumlar setinin de toplumdan topluma farklılaşmasına neden olacaktır. 


\section{KAYNAKÇA}

ACAR, Y. (1998), Büyüme Teorileri, Uludağ Üniversitesi Basımevi, Bursa.

ACEMOGLU D., ROBINSON, J. (2008), "The Role of Institutions in Growth and Development", Commission on Growth and Development, Working Paper, No. 10.

ACEMOGLU, D., JOHNSON, S., ROBINSON, J. (2004), "Institution as the Fundamental Cause of Long-Run Growth", NBER Working Paper, No.10481.

ACEMOGLU, D., JOHNSON, S., ROBINSON, J. (2002), "Reversal of Fortune: Geography and Institutions in the Making of the Modern World Income Distribution", Quarterly Journal of Economics, 117(4), 231-1294.

ACEMOGLU, D., JOHNSON, S., ROBINSON, J., THAICHAROEN, Y. (2003), "Institutional Causes, Macroeconomic Symptoms Volatility, Crises and Growth", Journal of Monetary Economics, 50, 49-123.

AHSAN, S. M. (2001), "Institutional Framework and Poverty", Wider Discussion Paper, No. 2001/136.

ALZER, M., DADASOV, R. (2013), "Financial Liberalization and Institutional Development", Economics \& Politics, 25(3), 424-451.

ARON, J. (2000), "Growth and Institutions: A Review of the Evidence", The World Bank Research Observer, 15(1).

BAKIMLI, E. (2005), "Uluslararası Rekabet Sürecinde Türkiye", Uluslararası Rekabet Gücü: Ölçümü ve Önemi, (Ed. M. F. Gökalp, C. Y. Kesbiç), Beyaz Yayınları, İstanbul, 3-54.

BARRO, R. J. (2002), "Quantity and Quality of Economic Growth", Working Papers Central Bank of Chile, 168, Central Bank of Chile, 135-162.

BARRO, R.J. (1996), "Determinants of Economic Growth: A Cross-Country Empirıcal Study", NBER Working Paper, No: 5698, 1-78.

BHAPPU, A.D. (2001), "Japon Ailesi: Japon Şirket Ağları ve Japon Yönetimi İçin Kurumsal Bir Mantık", (Çev. N. Atsan), Akdeniz Íktisadi ve İdari Bilimler Fakültesi Dergisi, (2), 156-167.

BORRMANN, A., BUSE, M., NEUHAUS, S. (2006), "Institutional Quality and the Gains from Trade", Kyklos, 59(3).

CHARNOCK, G. (2009), "Why do Institutions Matter? Global Competitiveness and the Politics of Policies in Latin Amerika", Capital ve Class, 33(2), 67-99. 


\section{A. YILDIRIM - M. F. GÖKALP}

CHEPTEA, A. (2007), "Trade Liberalization and Institutional Reforms", Economics of Transition, 15(2), 211-255.

CHEN, YU. (2008), "Opening-up or Institutional Development? Evidence from China", International Economic Journal, 22(4), 419-430.

COMMONS, J. R. (1931), “Institutional Economics”, American Economic Review, 21(4), 648-657.

DE HAAN, J., SIERMANN CLEMENS L. J. (1995), "New Evidence on the Relationship between Democracy and Economic Growth", Public Choice, 86, 175198.

DEANE, P. (2000). Illk Sanayi Inkılâbı. (Çev. T. Güran), 3. Baskı, Türk Tarih Kurumu Basımevi, Ankara.

DECKER, J. H., LIM, J. J. (2008), "What Fundamentally Drives Growth? Revisiting the Institutions and Economic Performance Debate", Journal of International Development, 20, 698-725.

DEMIR, Ö. (1996), Kurumcu İktisat, Vadi Yayınları, Ankara.

DOYLE, E., MARTINEZ-ZARZOSOF, I. (2011), "Productivity, Trade and Institutional Quality: A Panel Analysis", Southern Economic Journal, 77(3), 726752.

ELliOTT, K. A. (1997), "Corruption as An International Policy Problem: Overview and Recommendations", Corruption and The Global Economy, (Ed. K. A. Elliott), Institute for International Economics Publisher, 175-233.

FEDDERKE, J. (2001), "Growth and Institutions", Journal of International Development, (13), 645-670.

GANI, A., PRASAD, B. C. (2006). "Institutional Quality and Trade in Pacific Island Countries", Asia-Pacific Research and Training Network on Trade Working Paper Series, No. 20, (rev. 2/09).

GERTLER, M. S. (2010), "Rules of the Game: The Place of Institutions in Regional Economic Change", Regional Studies, 44(1), 1-15.

GROSSMAN, G. M., HELPMAN, E. (2002), Special Interest Politics, MIT Press, Cambridge.

GWARTNEY, J. D., HALL, J. C., LAWSON, R. (2010), Economic Freedom of the World: 2010 Annual Report. Vancouver, BC: The Fraser Institute, www.freetheworld.com. 
HALL, R. E., JONES, C. I. (1999), "Why Do Some Countries Produce so Much More Output Per Worker Than Others?", The Quarterly Journal of Economics, 114(1), 83-116.

HAMILTON, W. H. (1932), "Institutions", Encyclopaedia of the Social Sciences, (Ed. R. Edwin, A. Seligman, A. Johnson), 8, Macmillian, 84-89.

HENRY, P. B., MILlER, C. (2008), "Institutions vs. Policies: A Tale of Two Islands", NBER Working Paper Series, Working Paper 14604.

HIRA, A. (2009), "Learning from The Tigers-Comparing Innovation Institutions in Rapidly Developing Economies with Latin America", http://www.ejournal. unam.mx/pde/pde156/PDE004015606.pdf, (08.02.2012).

HODGSON, G. M. (2004), The Evolution of Institutional Economics: Agency, Structure and Darwinism in American Institutionalism. Routledge, London.

HODGSON, G. M. (1998), “The Approach of Institutional Economics”, Journal of Economic Literature. 36(1), 166-192.

KASPER, W., STREIT, M. E. (1998). "Kurumsal İktisat”, (Çev. B. Açıkgöz), http://www.canaktan.org/ekonomi/kurumsal-iktisat/makaleler/kasper-streit.htm, (27.10.2010).

KEIZER, P. (2007), "The Concept of Institutioan in Economics and Sociology, A Methodological Exposition", Utrecht School of Economics Tjalling C. Koopmans Research Institute, Discussion Paper Series, 07(25).

KERBER, W. (2006), "Competition, Knowledge and Institutions", Journal of Economic Issues, 40(2).

KHAN, Z. B., SOKOLOF, K. L. (2001), "The Early Development of Intellectual Property Institutions in the United States", Journal of Economic Perspectives, 15(3), 233-246.

KNACK, S., KEEFER, P. (1997), "Does Social Capital Have an Economic Payoff? A Cross - Country Investigation", The Quarterly Journal of Economics, 112(4), 1251-1288.

KOZLU, C. (1994), Türkiye Mucizesi İçin Vizyon Arayışları ve Asya Modelleri, Türkiye İş Bankası Kültür Yayınları, Ankara.

LE, T. (2009), "Trade, Remittances, Institutions and Economic Growth", International Economic Journal, 23(3), 391-408. 


\section{A. YILDIRIM - M. F. GÖKALP}

LEBLANG, D. A. (1996), "Property Rights, Democracy and Economic Growth", Political Research Quarterly, 49(1).

LEVCHENKO, A. A. (2004), "Institutional Quality and International Trade", IMF Working Paper, WP/04/231.

LUIZ, J. M. (2009)," Institutions and Economic Performance: Implications for African Development", Journal of International Development, (21).

MANSFIELD, Z. (2014), "Küresel Sistemde Endeksler Tuzağı", http://www.turcomoney.com/yazar/kuresel-sistemde-endeksler-tuzagi.html, (01.12.2014).

MARANGOS, J., ASTROULAKIS, N. (2009), "The Institutional Foundation of Development Ethics", Journal of Eoonomic Issues, 43(2), 381-388.

MEHLUM, H., MOENE, K., RAGNAR, T. (2006), "Institutions and The Resource Curse", The Economic Journal, (1169).

MEYER, D. C. (2008), France An Outline of History. Scholl of Modern Languages and Cultures The University of Hong Kong.

MIJIYAWA, A. G. (2008), "Sustained Economic Growth: Do Institutions Matter, and Which One Prevails?", Cato Journal, 28(3), 385-420.

NELSON, R. R. (2007), "Institutions and Economic Growth: Sharpening the Research Agenda", Journal of Economic Issues, 41(2).

NELSON, M. A., SINGH, R. D. (1998), Democracy, Economic Freedom, Fiscal Policy and Growth in LDCs: A Fresh Look. Economic Development and Cultural Change, The University of Chicago, Chicago, 677-696.

NORTH, D. C. (2010), Kurumlar, Kurumsal Değişim ve Ekonomik Performans. (2.Baskı), (Çev. G. Ç. Güven), Sabancı Üniversitesi, İstanbul.

NYE, J. (2008), "Institutions and the Institutional Environment", New Institutional Economics (Ed. E. Brousseau, J.M. Glachant), Cambridge University Press, New York, 67-80.

OLSON, M. (1996), "Distinguished Lecture on Economics in Government: Big Bills Left on The Sidewalk: Why Some Nations are Rich, and Others Poor", Journal of Economic Perspectives, 10(2), 3-24.

OPPER, S. (2008), "New Institutional Economics and Its Application on Transition and Developing Economies", New Institutional Economics, (Ed. E. Brousseau, J.M. Glachant), Cambridge University Press, New York, 389-405. 
PALDAM, M., WURTZ, A. (2003), The Big Bend: Economic Freedom and Growth, Universty of Aarhaus.

PRESBITERO, A. F. (2006), "Institutions and Geography as Sources of Economic Development", Journal of International Development, (18), 351-378.

POWELL, B. (2003), "Economic Freedom and Growth: The Case of The Celtic Tiger", Cato Journal, 22(3), 431-448.

REDEK, T., SUSJAN, A. (2005), "The Impact of Institutions on Economic Growth: The Case of Transition Economies", Journal of Economic Issues, 39(4).

REVERTE, C. (2008), "Institutional Differences in EU Countries and Their Relationship With Earnings Management Differences Implications For The PanEuropean Stock Market", Journal of Accounting ve Organizational Change, (4)2, $182-200$.

RICHTER, R. (2005), “The New Institutional Economics: Its Start, Its Meaning, Its Prospects", European Business Organization Law Review, (6), 161-200.

RODRIK, D. (2009), Tek Ekonomi Çok Reçete: Küreselleşme, Kurumlar ve Ekonomik Büyüme, (Çev. N. Domaniç), Eflatun Yayınevi, Ankara.

RODRIK, D., SUBRAMANIAN, A. (2003), "The Primacy of Institutions", Finance and Development, 40(2).

RODRIK, D. (2000), Yeni Küresel Ekonomi ve Gelişmekte Olan Ülkeler, Dışa Açılma Nasıl Gerçekleştirilmeli? (Çev. S.Gül), Sabah Kitapları Çağdaş Bakışlar Dizisi, İstanbul.

ROSENBERG, N., BIRDZELL JR, L. E. (1992), Batı Nasıl Zengin Oldu, Endüstri Dünyasının Ekonomik Değişimi, (Çev. E. Güven), Form Yayınları, İstanbul.

SACHS, J. D. (2003), "Institutions Matter, but not for Everything", Finance ve Development, 40(2).

SANDER, O. (1998), Siyasi Tarih İlk Çağlardan 1918'e, (6. Bask1), İmge Kitabevi, Ankara.

SAVAŞ, V. (2007), İktisatın Tarihi, Siyasal Kitabevi, Ankara.

SHIRLEY, M. M. (2008), Institutions and Development. Edward Elgar Publishing Limited, UK/USA. 


\section{A. YILDIRIM - M. F. GÖKALP}

SIROWY, L., INKELES, A. (1990), "The Effecs of Democracy on Economic Growth and Inequality: A Review", Studies in Comparative International Development, 25(1), 126-157.

SKOCPOL, T. (1987), States and Social Revolutions: A Comparetive Analysis of France, Russia and China. Cambridge University Press, Cambridge.

SMITH, A. (2004), Ulusların Zenginliği, (Çev. A. Yunus, M. Bakırc1), Alan Yayınc1l1k, İstanbul.

SVENSSON, J. (1998), "Investment Property and Political Instability: Theory and Evidence", European Economic Review, 42, 1317-1341.

TATOĞLU, F. Y. (2013), Panel Veri Ekonometrisi Stata Uygulamal, Beta Basım Yayım Dağıtım A.Ş., İstanbul.

ÜNSAL, E. (2007), Ikktisadi Büyüme, İmaj Yayınc1lı, Ankara.

VEBLEN, T. (1919), The Place of Science in Modern Civilisation and Other Essay, Huebsch, New York.

WEISS, L., HOBSON J. M. (1999), Devletler ve Ekonomik KalkinmaKarşılaştırılmalı Bir Tarihsel Analiz, (Çev. K. Dündar), Dost Yayınevi, Ankara.

WILLIAMSON, O. E. (2000), "The New Institutional Economics: Taking Stock, Looking Ahead", Journal of Economics Literature, (38), 595-613.

WILLIAMSON, O. E. (1985), The Economic Institutions of Capitalism Firms, Markets, Relational Contracting. The Free Press, Newyork.

WILSON, M. C. (2007), "Uncertainty and Probability in Institutional Economics", Journal of Economic Issues, 41(4).

WOLFEREN, K. V. (1992), Japon Gücünün Strrı, (Çev. İ. Kurmuş), Türkiye İş Bankası Kültür Yayınları, Ankara. 